\title{
Hypomagnesemia and functional hypoparathyroidism due to novel mutations in the Mg-channel TRPM6
}

\author{
Marianne C Astor ${ }^{1,2}$, Kristian Løvås ${ }^{1,2}$, Anette S B Wolff ${ }^{1}$, Bjørn Nedrebø ${ }^{3}$, \\ Eirik Bratland ${ }^{1}$, Jon Steen-Johnsen ${ }^{4}$ and Eystein S Husebye ${ }^{\mathbf{1 , 2}}$ \\ ${ }^{1}$ Department of Clinical Science, University of Bergen, Bergen, Norway \\ ${ }^{2}$ Department of Medicine, Haukeland University Hospital, Bergen, Norway \\ ${ }^{3}$ Department of Medicine, Haugesund Hospital, Haugesund, Norway \\ ${ }^{4}$ Pediatric Department, Telemark County Hospital, Skien, Norway
}

\author{
Correspondence \\ should be addressed \\ to M C Astor \\ Email \\ marianne.astor@ \\ helse-bergen.no
}

\begin{abstract}
Primary hypomagnesemia with secondary hypocalcemia (HSH) is an autosomal recessive disorder characterized by neuromuscular symptoms in infancy due to extremely low levels of serum magnesium and moderate to severe hypocalcemia. Homozygous mutations in the magnesium transporter gene transient receptor potential cation channel member 6 (TRPM6) cause the disease. HSH can be misdiagnosed as primary hypoparathyroidism. The aim of this study was to describe the genetic, clinical and biochemical features of patients clinically diagnosed with HSH in a Norwegian cohort. Five patients in four families with clinical features of HSH were identified, including one during a national survey of hypoparathyroidism. The clinical history of the patients and their families were reviewed and gene analyses of TRPM6 performed. Four of five patients presented with generalized seizures in infancy and extremely low levels of serum magnesium accompanied by moderate hypocalcemia. Two of the patients had an older sibling who died in infancy. Four novel mutations and one large deletion in TRPM6 were identified. In one patient two linked homozygous mutations were located in exon 22 (p.F978L) and exon 23 (p.G1042V). Two families had an identical mutation in exon 25 (p.E1155X). The fourth patient had a missense mutation in exon $4(\mathrm{p} . \mathrm{H} 61 \mathrm{~N})$ combined with a large deletion in the C-terminal end of the gene. HSH is a potentially lethal condition that can be misdiagnosed as primary hypoparathyroidism. The diagnosis is easily made if serum magnesium is measured. When treated appropriately with high doses of oral magnesium supplementation, severe hypomagnesemia is uncommon and the long-term prognosis seems to be good.
\end{abstract}

\section{Key Words}

- hypomagnesemia

- familial hypomagnesemia

- hypoparathyroidism

- transient receptor potential cation channel member 6

- TRPM6

\section{Introduction}

Primary hypoparathyroidism is a rare condition with multiple aetiologies, in adults most commonly caused by damage to the parathyroid glands by surgery or radiation, whereas autoimmune and genetic causes dominate in children. Hypoparathyroidism can be isolated or can be one component of a syndrome like DiGeorge syndrome, autoimmune polyglandular syndrome type 1 and other rarer syndromes. Transient hypocalcemia due to the relative resistance to parathyroid hormone (PTH) of the immature neonatal kidney can also be encountered in infancy. http://www.endocrineconnections.org DOI: 10.1530/EC-15-0066 (c) 2015 The authors Published by Bioscientifica Ltd
This work is licensed under a Creative Commons Attribution-NonCommercial 4.0 International License. 
Hypomagnesemia blocks the release of PTH and probably also decreases the sensitivity to circulating PTH in target organs and thereby causes a biochemical picture identical to primary hypoparathyroidism (1). Hypomagnesemia is usually caused by malnutrition or medication such as diuretics, proton pump inhibitors, cetuximab (epidermal growth factor (EGF) receptor inhibitor used for colon cancer), certain antibiotics and immunosuppressives. In rare cases, hypomagnesemia is hereditary $(2,3)$, either isolated or combined with other electrolytes disturbances like Bartter's and Gitelman's syndromes. Over the last decades several genetic forms of hypomagnesemia have been identified, including mutations in transient receptor potential cation channel member 6 (TRPM6), claudin 16 and 19, cyclin M2 (CNNM2) and the EGF. For review, see (4).

Primary hypomagnesemia with secondary hypocalcemia (HSH) is an autosomal recessive disease characterized by reduced intestinal absorption and renal reabsorption of magnesium (5). HSH is the only known hereditary cause of hypomagnesemia characterized by intestinal magnesium wasting, first described by Paunier et al. (6). The causative gene was later identified as TRPM6 $(7,8)$. TRPM6 is a cation channel that shows a higher affinity to magnesium than calcium $(9,10)$, expressed mainly in the intestinal epithelium and nephrons (7). It is responsible for active transcellular magnesium absorption in the intestine and active reabsorption in the kidneys, a key player to keep magnesium levels in the physiological range (11). Only at relatively high magnesium intake does passive absorption take place, which explains why high oral magnesium intake can partially compensate for the defective active absorption $(7,12)$.

HSH typically presents with generalized seizures or increased neuromuscular excitability such as muscle spasms or tetany during infancy $(12,13)$, but milder and later presentations have been reported $(14,15,16)$. HSH is sometimes misdiagnosed as primary hypoparathyroidism, due to the initial presenting symptoms of hypocalcemia and concomitant low or inappropriate normal PTH (14). A characteristic feature of the condition is an extremely low level of serum magnesium, in most cases below $0.4 \mathrm{mmol} / \mathrm{l}$, and usually accompanied by moderate hypocalcemia (13). The clinical symptoms of hypomagnesemia are not easily distinguished from the symptoms of hypocalcemia. Incorrect or delayed diagnosis and/or treatment can lead to fatal convulsions and chronic irreversible neurological complications $(13,17)$. Affected patients require lifelong replacement with high oral doses of magnesium. Here, we report the clinical and genetic characteristics of five patients in four families diagnosed in infancy with hypocalcemia and hypomagnesemia.

\section{Subjects and methods}

\section{Patients and design}

In a survey of Norwegian patients with hypoparathyroidism (Astor MC, Løvås K \& Husebye ES, unpublished observations), one patient (F1.1) was identified through a search in electronic hospital registries using the International Classification of diseases (ICD) 10 code E83.5 (disorders of calcium metabolism). Review of her medical record revealed functional hypoparathyroidism due to hypomagnesemia as the underlying cause. The other families described were subsequently identified by members of the national study group for hypoparathyroidism using the following criteria: chronic hypomagnesemia from first year of life combined with low serum calcium that was correctable upon administration of magnesium salts; high faecal magnesium in spite of hypomagnesemia. All the participants or their guardians gave written informed consent. The Ethics Committee of Western Norway approved the study.

Three of the patients (F2.1, F3.1, F4.1) previously described with suspected HSH $(18,19,20)$ were re-evaluated leading to the identification of the fifth patient (F3.2) (Fig. 1 and Table 1). All patients and families were Caucasian. Consanguinity was present in family 3 , where the index patient's (F3.2) father and maternal grandmother were fourth cousins (not shown in Fig. 1).

\section{Biochemical analyses and calculation of magnesium excretion}

Urine magnesium-creatinine ratio and serum magnesium were analysed using Modular P from Roche Diagnostics at the laboratory for Clinical Chemistry at Haukeland University Hospital. All other biochemical results were obtained from the patients' records, including calculation of faecal and urine magnesium excretion, measured by various methods; three of the patients (F2.1, F3.1 and F4.1) went through comprehensive absorption studies using radioactive magnesium $(18,19,20), \mathrm{F} 1.1$ had daily intake and faecal and urinary excretion measured on three consecutive days, whereas F3.2 had 24-h urine magnesium estimated. PTH values were taken from historical records and measured by various methods. In the evaluation of F2.1, F3.1 and F4.1, a C-terminal-specific RIA (21) was used. In all but one case (F3.2) these were first-generation PTH assays and thereby of limited clinical importance. 
Family 1

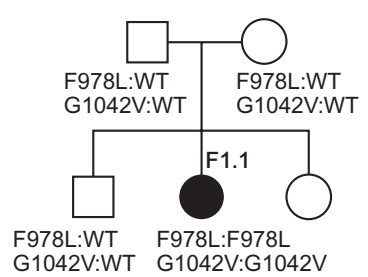

Family 3

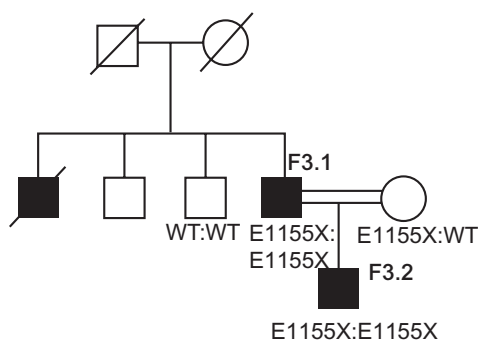

Figure 1

Families with primary hypomagnesemia with secondary hypocalcemia. Mutation statuses are shown for those family members where DNA was available for testing; affected individuals are shown with filled symbols. The identified mutation(s) and normal alleles (WT) are indicated beneath the symbols for all tested individuals. Deceased individuals are marked by a diagonal line.

\section{Mutational analyses}

Sequencing of the whole coding region of the TRPM6 gene was performed at the Laboratory for Molecular Diagnostics, Centre for Nephrology and Metabolic Disorders (Weisswasse, Germany), by Dr.med. Mato Nagel. Family members were screened for the family mutation by standard Sanger sequencing. Genomic DNA was extracted from whole blood by the QIAamp DNA Blood mini kit from Qiagen following the manufacturer's protocol. Copy number variation analysis was performed using a duplex real-time PCR assay in which the number of copies of the TRPM6 gene was compared to the copy number of an internal standard gene (RNaseP from Applied Biosystem). The assay for copy number variation was performed for five different sites of the gene (intron 3 and exon 4, 20, 30 and 39). Primers, probes and assay conditions are available upon request.

\section{Results}

\section{Clinical presentation}

F1.1 presented with seizures during an episode with fever at the age of 9 months, considered as febrile convulsions. After a second episode, severe hypomagnesemia

http://www.endocrineconnections.org
$\begin{array}{lr}\text { DOI: } 10.1530 / \text { EC-15-0066 } 2015 \text { The authors } \\ \text { Published by Bioscientifica Ltd }\end{array}$

(0.16 mmol/1, reference range 0.71-0.94) and hypocalcemia ( $1.30 \mathrm{mmol} / \mathrm{l}$, reference range $2.20-2.55)$ were discovered (Table 1). Treatment with both intravenous calcium and magnesium salts were given and electrolytes normalized.

F2.1 had symptoms of generalized seizures from the age of 6 weeks. Clinical examination revealed muscular hyperirritability, positive Chvostek's sign and carpopedal spasms. He had moderately low serum calcium at $1.90 \mathrm{mmol} / \mathrm{l}$ accompanied by low serum magnesium at $0.25 \mathrm{mmol} / \mathrm{l}$. Magnesium was given intravenously, which resulted in normalization of both calcium and magnesium levels. No further seizures were noted. An older brother had died at 7 weeks of age due to persistent hypocalcemic seizures resistant to calcium and vitamin D therapy, indicating HSH as the cause of death. Serum magnesium was not measured, and magnesium salts were not given.

F3.1 was admitted to hospital at the age of 4 weeks with stiffness and opisthotonus. He received treatment with anticonvulsants, which resulted in temporary improvement. However, symptoms recurred and hypomagnesemia and hypocalcemia was then discovered. He was successfully treated with intravenous magnesium, and later oral replacement. An older brother had died at 8 weeks old due to 'muscular weakness' (further details on his medical history were not found). F3.2 had twitching of extremities and regurgitation from birth. Serum magnesium was measured at the age of 10 days, the HSH diagnosis made and properly treated, and he has never experienced serious hypomagnesemia symptoms.

F4.1 had repeated tetanic convulsions at the age of 4 weeks. On admission serum calcium was $1.85 \mathrm{mmol} / \mathrm{l}$, but calcium infusions neither relieved symptoms nor increased serum calcium levels; on the contrary, calcium gradually declined to a minimum of $1.35 \mathrm{mmol} / \mathrm{l}$. After discovering low serum magnesium of $0.25 \mathrm{mmol} / \mathrm{l}$, parenteral magnesium therapy was given with normalization of serum calcium, near normalization of magnesium and complete disappearance of tetany. After the diagnosis was properly made, the patient has received continuous oral magnesium supplementation. In the first year of life he had two further episodes of seizures at the age of 6 and 10 months, the last of which appeared during febrile illness.

\section{Treatment and complications}

All the patients were treated with oral magnesium hydroxide, on average $19 \mathrm{mg} / \mathrm{kg}$ per day (range 10$38 \mathrm{mg} / \mathrm{kg}$ per day). Dose increments were limited by diarrhoea, and serum magnesium levels were constantly

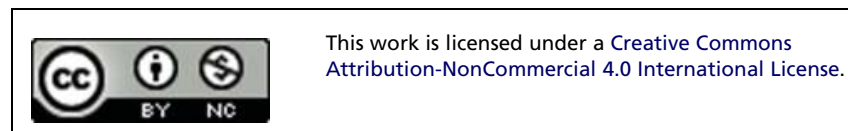


Table 1 Clinical and biochemical characteristics of patients with HSH. Patient F2.1, F3.1 and F4.1 were clinically described in former reports $(18,19,20)$.

\begin{tabular}{|c|c|c|c|c|c|}
\hline Patient & $\mathbf{F 1 . 1}$ & $\mathbf{F 2 . 1}$ & F3.1 & $\mathbf{F 3 . 2}$ & F4.1 \\
\hline Age (years) & 26 & 46 & 44 & 10 & 47 \\
\hline Gender & $\mathrm{F}$ & $\mathrm{M}$ & $\mathrm{M}$ & $\mathrm{M}$ & $\mathrm{M}$ \\
\hline \multicolumn{6}{|l|}{ Clinical and laboratory data at presentation } \\
\hline Age & 9 months & 3 weeks & 4 weeks & 10 days & 4 weeks \\
\hline Presentation & Seizures & Seizures & $\begin{array}{l}\text { Stiffness and } \\
\text { opisthotonus }\end{array}$ & $\begin{array}{l}\text { Twitching of } \\
\text { extremities }\end{array}$ & Seizures \\
\hline $\mathrm{S}-\mathrm{Mg}(\mathrm{mmol} / \mathrm{l})$ ref. range $0.71-0.94$ & 0.16 & 0.25 & NA & 0.23 & 0.25 \\
\hline S-Ca $(\mathrm{mmol} / \mathrm{l})$ ref. range $2.20-2.55$ & 1.37 & 1.90 & NA & 2.55 & 1.35 \\
\hline Faecal Mg-excretion ( $\%$ of oral intake) ${ }^{a}$ & Increased $^{a}$ & $91 \%$ & $82 \%$ & NA & $88 \%$ \\
\hline \multicolumn{6}{|l|}{ Urinary Mg-excretion } \\
\hline$\%$ of absorbed oral intake ${ }^{b}$ & $4 \%$ & $7 \%$ & NA & - & $2 \%$ \\
\hline $\mathrm{mmol} / \mathrm{mol}$ creatinine ${ }^{\mathrm{c}}$ & - & - & - & 3.9 & - \\
\hline \multicolumn{6}{|l|}{ With stable oral magnesium supplementation } \\
\hline $\begin{array}{l}\text { Daily oral Mg supplementation } \\
(\mathrm{mmol} / \mathrm{kg} \text { per day })^{d}\end{array}$ & $0.8-1.0$ & 0.5 & 0.4 & 0.5 & 1.6 \\
\hline Side effects of oral Mg & Diarrhea & Diarrhea & Diarrhea & None & None \\
\hline Serum-Mg (mmol/l) & $0.5-0.6$ & 0.6 & $0.6-0.7$ & $0.7-0.8$ & 0.7 \\
\hline $\begin{array}{l}\text { Urine-Mg ( } \mathrm{mmol} / \mathrm{mmol} \text { creatinine) } \\
\text { ref. range } 0.20-0.50\end{array}$ & 0.03 & 0.12 & 0.04 & 0.23 & 0.58 \\
\hline Other medications & Spironolactone & None & None & None & $\begin{array}{l}\text { Immuno- } \\
\text { suppressants }\end{array}$ \\
\hline \multicolumn{6}{|l|}{ TRPM6 mutations } \\
\hline Nucleotide exchange & $\begin{array}{l}\text { 1) } c .2934 C>G \\
\text { 2) } c .3125 G>T\end{array}$ & c.3463G > T & c.3463G $>\mathrm{T}$ & c.3463G $>$ T & $\begin{array}{l}\text { 1) } \mathrm{c} .181 \mathrm{C}>\mathrm{A} \\
\text { 2) Deletion }\end{array}$ \\
\hline Location & $\begin{array}{l}\text { 1) Exon } 22 \\
\text { 2) Exon } 23\end{array}$ & Exon 25 & Exon 25 & Exon 25 & $\begin{array}{l}\text { 1) Exon } 4 \\
\text { 2) Between exon } \\
30 \text { and } 39\end{array}$ \\
\hline Consequence protein & $\begin{array}{l}\text { 1) p.F978L } \\
\text { 2) p.G1042V }\end{array}$ & p.E1155X & p.E1155X & p.E1155X & 1) p.H61N \\
\hline
\end{tabular}

NA, not available.

a'With normal magnesium levels and intake, about $50-80 \%$ is excreted in feces. In hypomagnesemia or with low intake, the intestine is normally able to reduce excretion to $10-20 \%(39,40)$

In magnesium depletion fractional renal excretion above $2 \%$ indicates renal wasting.

${ }^{c}$ Renal magnesium excretion ( $\mathrm{mmol} / \mathrm{mol}$ creatinine) should be below 2 in healthy infants.

${ }^{\mathrm{d}}$ Approximately $0.15-0.20 \mathrm{mmol} / \mathrm{kg}$ per day in healthy people.

in the subnormal range in all patients (Table 1). After diagnosis and adequate treatment one of the patients had an episode of seizures (F2.1) when not adhering to magnesium supplementation. F1.1 was hospitalized at 21 years of age because of dysarthria, lethargy, vomiting, headache and paraesthesia of her face and hands, but without convulsions. Physical examination revealed general muscle weakness and dysarthria, but was otherwise normal. Biochemical tests revealed serum magnesium at $0.40 \mathrm{mmol} / \mathrm{l}$ and albumin-corrected calcium at $1.64 \mathrm{mmol} / \mathrm{l}$. Corrections of the electrolyte disturbances with intravenous magnesium salt resulted in rapid clinical improvement. On discharge she reinstated her usual oral magnesium supplementation, which yielded serum magnesium levels at $0.2-0.6 \mathrm{mmol} / \mathrm{l}$, with persistent symptoms of lethargy and frequent need of intravenous

$\begin{array}{lr}\text { http://www.endocrineconnections.org } & \text { ( } 2015 \text { The authors } \\ \text { DOI: } 10.1530 / \text { EC-15-0066 } & \text { Published by Bioscientifica Ltd }\end{array}$

magnesium infusions. After adding $50 \mathrm{mg}$ spironolactone, the magnesium levels have been stable in the subnormal range with a less frequent need for intravenous magnesium. Patient F4.1 died during the study period at the age of 47 of causes unrelated to HSH.

\section{Biochemical phenotype}

Study of the magnesium balance in childhood (F1.1, F2.1, F3.1 and F4.1) demonstrated that faecal magnesium excretion was high despite of hypomagnesemia (Table 1). Testing during childhood also showed that urinary magnesium excretion was low, but nevertheless inappropriately high relative to the hypomagnesemia. Patient F3.2 had a low PTH of 0.1 pmol/l (reference range 1.3-6.8) at the time of diagnosis. None of the other

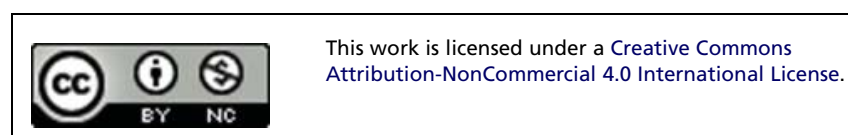


patients had PTH measured at the time of diagnosis, but PTH values during stable oral magnesium supplementation (F1.1) and during clinical testing without magnesium supplementation for 5 days to 2 weeks (F2.1, F3.1, F4.1) (18) were within the normal reference range in all the other patients. Serum magnesium levels in both heterozygous gene carriers and unaffected family members were normal (0.81-0.90 mmol/l).

\section{Gene analysis of TRPM6}

All patients exhibited mutations in the TRPM6 gene (Fig. 2). Four novel mutations and one deletion were identified (Table 1). F1.1 had two novel missense mutations in exons 22 and 23 respectively and was homozygous for both mutations. Copy number analysis revealed two copies of the gene throughout the whole sequence. The parents and the tested sibling were heterozygous for the same mutations, all of them with normal electrolytes. The mutation in exon 22 (F978L) is located in one of the transmembrane segments of the TRPM6 protein, whereas the mutation in exon 23 $(\mathrm{G} 1042 \mathrm{~V})$ is located at the putative pore-forming region of the protein. Members of families 2 and 3 harboured a homozygous nonsense mutation (p.E1155X) in exon 25 just proximal of the $\alpha$-kinase domain giving a truncated protein. In family 4 , we first identified a missense mutation in a highly conserved histidine (p.H61N) in exon 4. Subsequent copy number analysis revealed a deletion in the other allele, consistent with a compound heterozygous genotype. The mother carried the deletion, located at the C-terminal end between exons 30 and 39 (two copies in intron 3, exons 3, 20 and 30, but only 1 copy in exon 39 ; boundaries not further localized).

\section{Discussion}

We here describe five patients in four families with severe childhood hypomagnesemia and $\mathrm{HSH}$ confirmed by mutational analyses of the TRPM6 gene. The index patients in all families presented in infancy with seizures and/or tetany, indicating hypocalcemia. Based on our cohort, a very rough estimate yields a minimum prevalence of one per million in the Norwegian population. One may speculate if the true prevalence is higher due to undiagnosed cases.

HSH is inherited in an autosomal recessive manner, except in a family described by Walder in which only one mutation was found, a C-to-T transition in exon 4 (R56X). However, a large deletion could have been present as was the situation in our family 4 and other cases reported in the literature $(7,13)$. A few cases of late presentations of

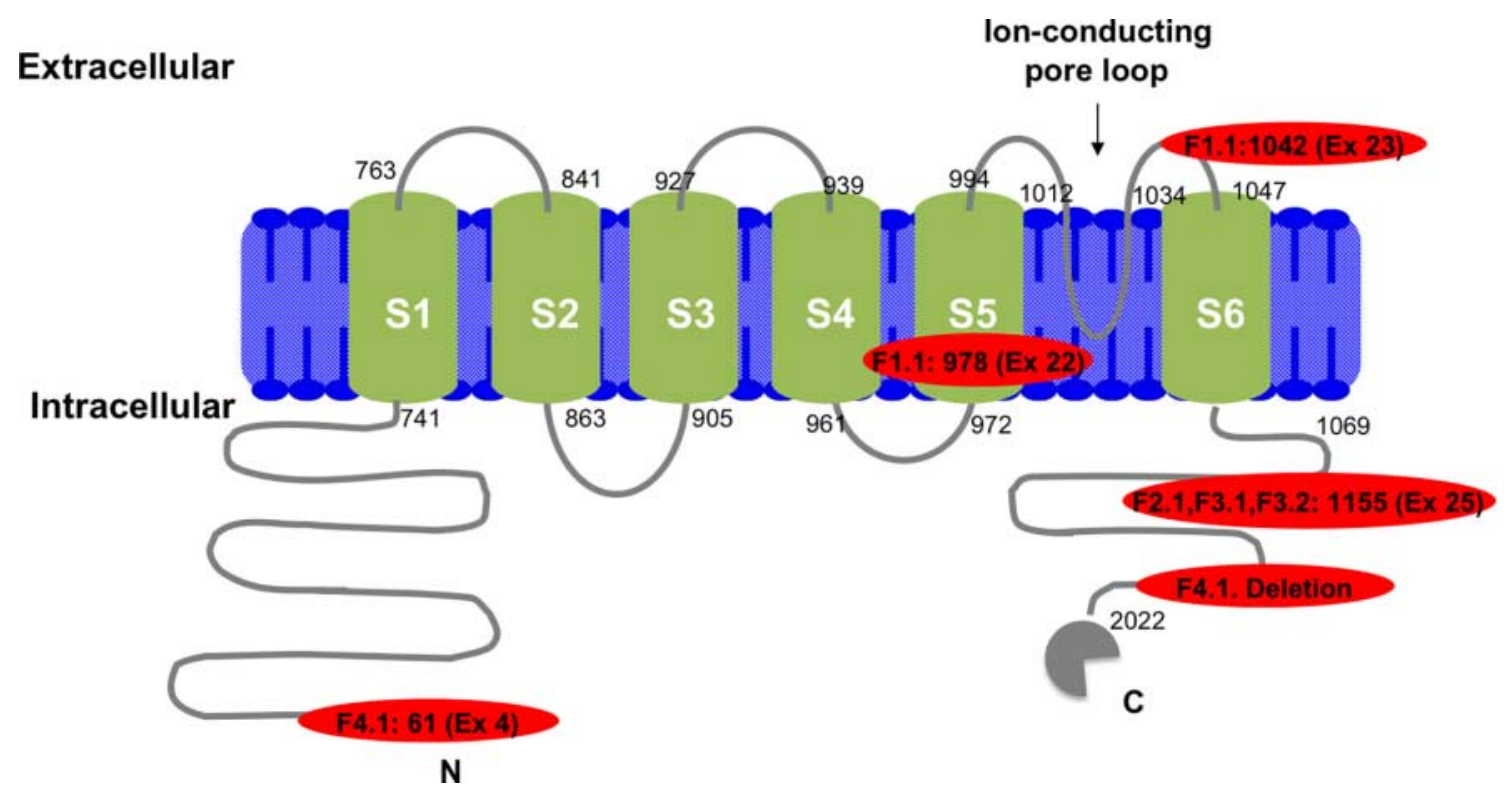

Figure 2

Schematic illustration of the TRPM6 gene with the novel mutations and the deletion indicated. Mutations in exon 4, 22 and 23 are missense mutations located in conserved residues. The mutation in exon 25 is a non-sense mutation. The mutation in exon 4 and the deletion at the $\mathrm{C}$-terminal end is a compound heterozygote mutation (patient F4.1). The horizontal bars indicate the location of the mutations and the deletion, linked to the relevant case(s).
This work is licensed under a Creative Commons Attribution-NonCommercial 4.0 International License. http://www.endocrineconnections.org DOI: 10.1530/EC-15-0066 (c) 2015 The authors Published by Bioscientifica Ltd

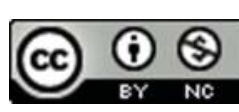


clinical HSH have been described, all prior to the identification of the causative gene. Whether these are caused by mutations in TRPM6 is unclear. Heterozygous mutation carriers are asymptomatic with normal serum magnesium, in contrast to heterozygous mice, which have mild hypomagnesemia $(22,23)$. Homozygous TRPM6 ${ }^{-1-}$ mice exhibit a more severe phenotype than humans, with increased embryonic lethality and induce a high mortality rate for those who survive to term. As far as we know, F3.2 is the first described offspring of a patient with HSH. TRPM6 are also expressed in the testicles, but the clinical impact of the mutation on the male fertility is unknown.

The clinical presentation in our study was very similar to previously described cases $(12,13)$ and demonstrates the importance of early identification and treatment of the disease. Dysarthria in the setting of $\mathrm{HSH}$, seen also in patient F1.1, has been reported earlier (13), and also in the hypomagnesemia caused by renal failure (24). The typical constellation with extreme hypomagnesemia combined with moderate hypocalcemia was present in all but one patient (F3.2) who had normal calcium levels at the time of diagnosis only 10 days after birth. Faecal and urinary magnesium excretion was high in those patients from whom we had available results, as expected in HSH.

HSH patients are usually well managed on oral magnesium supplementation without severe complications if they adhere to the treatment. Our patients had average disease duration of over 40 years without serious complications. One of the patients had an episode of dysarthria - in our experience an atypical symptom in hypomagnesemia - after a period of non-compliance, and has needed regularly intravenous magnesium supplementation in addition to high daily oral doses for several years to overcome symptomatic hypomagnesemia. The average daily magnesium dose used in the adult patients was $1000 \mathrm{mg}$ ( $15 \mathrm{mg} / \mathrm{kg}$, corresponding to $0.6 \mathrm{mmol} / \mathrm{kg}$ ) similar to another report $(0.93 \mathrm{mmol} / \mathrm{kg})$ (13). Diarrhoea is the main limiting factor for dosing. All the Norwegian patients were treated with magnesium hydroxide, even if studies indicate better absorption and fewer problems with loose stools with magnesium chloride or magnesium lactate (25). Treatment with spironolactone was effective in increasing the serum magnesium in one of the patients. High doses of spironolactone have been shown to reduce magnesuria in Gitelman's syndrome (26) and control subjects, but studies on magnesium excretion in response to low-dose spironolactone are sparse. Conversely, there is ample documentation of the magnesium-sparing effect of amiloride, which reduces the magnesium excretion regardless of the cause of hypomagnesemia $(27,28,29)$. A study by Murdoch et al. (29) found that amiloride but not spironolactone was associated with a dose-related increase in plasma magnesium in thiazide treated patients.

Until now, 48 different pathogenic mutations in the TRPM6 gene have been published $(7,8,13,30,31,32,33$, $34,35,36,37)$ and about 70 cases with HSH have been published worldwide. Mutations in TRPM6 are spread throughout the whole gene, without clustering in any specific domain (13). This is also reflected by the novel mutations detected in the current study. The mutation in exon 22, F978L, probably disrupts a membrane spanning $\alpha$-helix crucial for the TRPM6 channel activity, while the mutation in exon 23, G1042V, might affect the composition of the ion pore itself. Both of the mutated amino acids are conserved through evolution, indicating essential roles for proper function of the ion channel.

The mutation in exon 25, E155X, creates a premature stop-codon, resulting in a truncated TRPM6 protein without kinase activity. The H61N mutation, also a highly conserved amino acid, is located in a poorly described region of the TRPM6 protein, but it has been proposed that the N-terminal intracellular domain of TRPM6 is crucial for oligomerization (38).

In conclusion, HSH is a rare cause of hypomagnesemia, hypocalcemia and functional hypoparathyroidism, illustrated here in four families with five novel gene defects in TRPM6. An early diagnosis of HSH is crucial and the possibility of TRPM6 mutations should be known to both paediatricians and adult endocrinologists. As this condition is clinically indistinguishable from hypocalcemia, the measurement of serum magnesium is mandatory in the setting of hypocalcemia.

\section{Declaration of interest}

The authors declare that there is no conflict of interest that could be perceived as prejudicing the impartiality of the research reported.

\section{Funding}

The study was supported by funding from the Norwegian Directorate of Health and the Regional Health Authorities of Western Norway. M C Astor is a PhD candidate funded by the University of Bergen.

\section{Author contribution statement}

M C Astor, K Løvås, B G Nedrebø, J Steen-Johnsen and E S Husebye participated in study design and identification of patients, interpretation of the data, writing and critical revision of the manuscript. A S B Wolff and E Bratland designed and performed the genetic analyses and revised the manuscript. 


\section{Acknowledgements}

We are very grateful to the participating patients and their families for their cooperation. We also thank Mrs Elisabeth Halvorsen and Ms Hajirah Muneer for expert technical assistance.

\section{References}

1 Garty R, Alkalay A \& Bernheim JL. Parathyroid hormone secretion and responsiveness to parathyroid hormone in primary hypomagnesemia. Israel Journal of Medical Sciences 198319 345-348.

2 Swaminathan R. Magnesium metabolism and its disorders. Clinical Biochemist. Reviews 200324 47-66.

3 Martin KJ, Gonzalez EA \& Slatopolsky E. Clinical consequences and management of hypomagnesemia. Journal of the American Society of Nephrology 200920 2291-2295. (doi:10.1681/ASN.2007111194)

4 de Baaij JH, Hoenderop JG \& Bindels RJ. Magnesium in man: implications for health and disease. Physiological Reviews 201595 1-46. (doi:10.1152/physrev.00012.2014)

5 Milla PJ, Aggett PJ, Wolff OH \& Harries JT. Studies in primary hypomagnesaemia: evidence for defective carrier-mediated small intestinal transport of magnesium. Gut 197920 1028-1033. (doi:10.1136/gut.20.11.1028)

6 Paunier L, Radde IC, Kooh SW, Conen PE \& Fraser D. Primary hypomagnesemia with secondary hypocalcemia in an infant. Pediatrics 196841 385-402.

7 Schlingmann KP, Weber S, Peters M, Niemann Nejsum L, Vitzthum H, Klingel K, Kratz M, Haddad E, Ristoff E, Dinour D et al. Hypomagnesemia with secondary hypocalcemia is caused by mutations in TRPM6, a new member of the TRPM gene family. Nature Genetics 200231 166-170. (doi:10.1038/ng889)

8 Walder RY, Landau D, Meyer P, Shalev H, Tsolia M, Borochowitz Z, Boettger MB, Beck GE, Englehardt RK, Carmi R et al. Mutation of TRPM6 causes familial hypomagnesemia with secondary hypocalcemia. Nature Genetics 200231 171-174. (doi:10.1038/ng901)

9 Voets T, Nilius B, Hoefs S, van der Kemp AW, Droogmans G, Bindels RJ \& Hoenderop JG. TRPM6 forms the $\mathrm{Mg}^{2+}$ influx channel involved in intestinal and renal $\mathrm{Mg}^{2+}$ absorption. Journal of Biological Chemistry 2004279 19-25. (doi:10.1074/jbc.M311201200)

10 Schlingmann KP, Waldegger S, Konrad M, Chubanov V \& Gudermann T. TRPM6 and TRPM7 - gatekeepers of human magnesium metabolism. Biochimica et Biophysica Acta 20071772 813-821. (doi:10.1016/j.bbadis.2007.03.009)

11 Konrad M, Schlingmann KP \& Gudermann T. Insights into the molecular nature of magnesium homeostasis. American Journal of Physiology. Renal Physiology 2004286 F599-F605. (doi:10.1152/ ajprenal.00312.2003)

12 Shalev H, Phillip M, Galil A, Carmi R \& Landau D. Clinical presentation and outcome in primary familial hypomagnesaemia. Archives of Disease in Childhood 199878 127-130. (doi:10.1136/adc.78.2.127)

13 Schlingmann KP, Sassen MC, Weber S, Pechmann U, Kusch K, Pelken L, Lotan D, Syrrou M, Prebble JJ, Cole DE et al. Novel TRPM6 mutations in 21 families with primary hypomagnesemia and secondary hypocalcemia. Journal of the American Society of Nephrology 200516 3061-3069. (doi:10.1681/ASN.2004110989)

14 Jin-no Y, Kamiya Y, Okada M, Hirako M, Takada N \& Kawaguchi M. Primary hypomagnesemia caused by isolated magnesium malabsorption: atypical case in adult. Internal Medicine 199938 261-265. (doi:10.2169/internalmedicine.38.261)

15 Romero R, Meacham LR \& Winn KT. Isolated magnesium malabsorption in a 10-year-old boy. American Journal of Gastroenterology 199691 611-613.

16 Anast CS, Mohs JM, Kaplan SL \& Burns TW. Evidence for parathyroid failure in magnesium deficiency. Science 1972177 606-608. (doi:10.1126/science.177.4049.606)
17 Walder RY, Shalev H, Brennan TM, Carmi R, Elbedour K, Scott DA Hanauer A, Mark AL, Patil S, Stone EM et al. Familial hypomagnesemia maps to chromosome $9 \mathrm{q}$, not to the $\mathrm{X}$ chromosome: genetic linkage mapping and analysis of a balanced translocation breakpoint. Human Molecular Genetics 19976 1491-1497. (doi:10.1093/hmg/6.9.1491)

18 Stromme JH, Steen-Johnsen J, Harnaes K, Hofstad F \& Brandtzaeg P. Familial hypomagnesemia - a follow-up examination of three patients after 9 to 12 years of treatment. Pediatric Research 198115 1134-1139. (doi:10.1203/00006450-198108000-00012)

19 Stromme JH, Nesbakken R, Normann T, Skjorten F, Skyberg D \& Johannessen B. Familial hypomagnesemia. Biochemical, histological and hereditary aspects studied in two brothers. Acta Paediatrica Scandinavica 196958 433-444. (doi:10.1111/j.1651-2227.1969.tb04743.x)

20 Skyberg D, Stromme JH, Nesbakken R \& Harnaes K. Neonatal hypomagnesemia with selective malabsorption of magnesium - a clinical entity. Scandinavian Journal of Clinical and Laboratory Investigation 196821 355-363. (doi:10.3109/00365516809077007)

21 Gautvik KM, Teig V, Halvorsen JF, Arnesen E, Myhre L, Heimann P \& Tollman R. Development of sequence specific radioimmunoassay of human parathyroid hormone and its use in the diagnosis of hyperparathyroidism. Scandinavian Journal of Clinical and Laboratory Investigation 197939 469-478. (doi:10.3109/00365517909106133)

22 Woudenberg-Vrenken TE, Sukinta A, van der Kemp AW, Bindels RJ \& Hoenderop JG. Transient receptor potential melastatin 6 knockout mice are lethal whereas heterozygous deletion results in mild hypomagnesemia. Nephron. Physiology 2011117 p11-p19. (doi:10. 1159/000320580)

23 Walder RY, Yang B, Stokes JB, Kirby PA, Cao X, Shi P, Searby CC, Husted RF \& Sheffield VC. Mice defective in Trpm6 show embryonic mortality and neural tube defects. Human Molecular Genetics 200918 4367-4375. (doi:10.1093/hmg/ddp392)

24 Satish R \& Gokulnath G. Serum magnesium in recovering acute renal failure. Indian Journal of Nephrology 200818 101-104. (doi:10.4103/ 0971-4065.43688)

25 Graziani G, Fedeli C, Moroni L, Cosmai L, Badalamenti S \& Ponticelli C. Gitelman syndrome: pathophysiological and clinical aspects. OJM 2010 103 741-748. (doi:10.1093/qjmed/hcq123)

26 Colussi G, Rombola G, De Ferrari ME, Macaluso M \& Minetti L. Correction of hypokalemia with antialdosterone therapy in Gitelman's syndrome. American Journal of Nephrology 199414 127-135. (doi:10.1159/000168701)

27 Ryan MP. Magnesium- and potassium-sparing effects of amiloride. Review and recent findings. Magnesium 19843 274-288.

28 Ryan MP. Magnesium and potassium-sparing diuretics. Magnesium 19865 282-292.

29 Murdoch DL, Forrest G, Davies DL \& McInnes GT. A comparison of the potassium and magnesium-sparing properties of amiloride and spironolactone in diuretic-treated normal subjects. British Journal of Clinical Pharmacology 199335 373-378. (doi:10.1111/j.1365-2125. 1993.tb04153.x)

30 Jalkanen R, Pronicka E, Tyynismaa H, Hanauer A, Walder R \& Alitalo T Genetic background of HSH in three Polish families and a patient with an X;9 translocation. European Journal of Human Genetics 200614 55-62.

31 Chubanov V, Schlingmann KP, Waring J, Heinzinger J, Kaske S, Waldegger S, Mederos y Schnitzler M \& Gudermann T. Hypomagnesemia with secondary hypocalcemia due to a missense mutation in the putative pore-forming region of TRPM6. Journal of Biological Chemistry 2007282 7656-7667. (doi:10.1074/jbc.M611117200)

32 Habeb AM, Al-Harbi H \& Schlingmann KP. Resolving basal ganglia calcification in hereditary hypomagnesemia with secondary hypocalcemia due to a novel TRPM6 gene mutation. Saudi Journal of Kidney Diseases and Transplantation 201223 1038-1042. (doi:10.4103/ 1319-2442.100945)

33 Lainez S, Schlingmann KP, van der Wijst J, Dworniczak B, van Zeeland F, Konrad M, Bindels RJ \& Hoenderop JG. New TRPM6 missense mutations linked to hypomagnesemia with secondary 
hypocalcemia. European Journal of Human Genetics 201422 497-504. (doi:10.1038/ejhg.2013.178)

34 Guran T, Akcay T, Bereket A, Atay Z, Turan S, Haisch L, Konrad M \& Schlingmann KP. Clinical and molecular characterization of Turkish patients with familial hypomagnesaemia: novel mutations in TRPM6 and CLDN16 genes. Nephrology, Dialysis, Transplantation 201227 667673. (doi:10.1093/ndt/gfr300)

35 Katayama K, Povalko N, Yatsuga S, Nishioka J, Kakuma T, Matsuishi T \& Koga Y. New TRPM6 mutation and management of hypomagnesaemia with secondary hypocalcaemia. Brain \& Development 201537 292-298. (doi:10.1016/j.braindev.2014.06.006)

36 Esteban-Oliva D, Pintos-Morell G \& Konrad M. Long-term follow-up of a patient with primary hypomagnesaemia and secondary hypocalcaemia due to a novel TRPM6 mutation. European Journal of Pediatrics 2009 168 439-442. (doi:10.1007/s00431-008-0767-1)
37 Zhao Z, Pei Y, Huang X, Liu Y, Yang W, Sun J, Si N, Xing X, Li M, Wang $\mathrm{O}$ et al. Novel TRPM6 mutations in familial hypomagnesemia with secondary hypocalcemia. American Journal of Nephrology 201337 541-548. (doi:10.1159/000350886)

38 Chubanov V, Waldegger S, Mederos y Schnitzler M, Vitzthum H, Sassen MC, Seyberth HW, Konrad M \& Gudermann T. Disruption of TRPM6/TRPM7 complex formation by a mutation in the TRPM6 gene causes hypomagnesemia with secondary hypocalcemia. PNAS 2004 101 2894-2899. (doi:10.1073/pnas.0305252101)

39 Quamme GA. Recent developments in intestinal magnesium absorption. Current Opinion in Gastroenterology 200824 230-235. (doi:10.1097/ MOG.0b013e3282f37b59)

40 Graham LA, Caesar JJ \& Burgen AS. Gastrointestinal absorption and excretion of $\mathrm{Mg}^{28}$ in man. Metabolism: Clinical and Experimental 19609 646-659.

Received in final form 26 July 2015

Accepted 13 August 2015
(C) 2015 The authors Published by Bioscientifica Ltd
This work is licensed under a Creative Commons Attribution-NonCommercial 4.0 International License. 